\title{
Mechanical analysis of the mandible fixed with the plate by FEM
}

\author{
○学貞金 崇文* （近大生物理工院） \\ 正 松本 俊郎* （近大生物理工） \\ 本橋 具和 ${ }^{* *}$ (大阪歯科大口腔外科学第二講座) \\ 山崎 行庸 $^{* *}$ (大阪歯科大口腔外科学第二講座) \\ 大西 祐一* (大阪歯科大口腔外科学第二講座) \\ 中嶋 正博** (大阪歯科大口腔外科学第二講座) \\ 覚道 健治** (大阪菊科大口腔外科学第二講座)
}

*Takafumi SADAKANE, Toshiro MATSUMOTO, Faculty of Biology-Oriented Sci. \&Tech., Kinki University, 930, Nishimitani, Uchita-cho, Naga-gun, Wakayama, 649-6493

** Tomokazu MOTOHASHI, Yukinobu YAMAZAKI,Yuichi ONISHI, Masahiro NAKAJIMA, Kenji KAKUDO,

Second Dept. of Oral \& Maxillofacial Surgery, Osaka Dental University, 1-5-17, Otemae, Chuo-ku,Osaka,540-0008

The mechanical characteristics of the mandible after bilateral sagittal split osteotomy through the use of 2 different plates to stabilize the osteotomy were compared by using three-dimensional finite element method. Three dimensional models were developed based on the geometry reconstructed from computed tomography. Straight(I-type) and L-type plates with 4 cortical screws were used to stabilize the osteotomy. A $41.6 \mathrm{~N}$ univertical compressive load was applied above left first molar in downward direction. To evaluate the mechanical characteristics of these 2 plates, following two items were compared:1)the resulting deflections at the central incisor of left side, 2)the mechanical stresses developed at the 4 screws of the stabilizing plates. The smaller deflection was found at the central incisor of L-type plate and the plate suggested higher mechanical stability. The lower mechanical stresses were acting on the L-type plate, whereas I-type plate is associated with higher values.

Key word: Stress distribution, finite element method(FEM), osteotomy, Plate

1. 緒言

下顎前突症の治療に関して、下顎枝矢状分割後骨接合を強 固にするため様々な固定方法が使われている。

これらの方法により臨床的には骨接合が行われているが、 力学的特性を定量的に調べた研究は十分に行われていない。 ヒトの䫟に対して直接、実験的に力学的特性を測定すること は生体に対する実験条件、測定方法等を検討すると困難であ る。有限要素法による下顎骨のモデル化および力学解析を行 、比較検討することは有意義であると考えられる。そこで本 研究では、下顎枝前突症の外科的治療に用いられる下顎枝矢 状分割法に関して分割したモデルを作成しストレート（以 下 I 型)と L 型各タイプの 2 種類のプレート固定性について 解析を行い、その結果について比較検討した。

2. 材料と方法

2.1 CT 撮影装置による画像とモデリング

買変形症患者の下頻骨の下部より頭頂部迄 CT 撮影装置 $(\mathrm{Hi}$ Speed Advantage, GE Medical System 社製)により撮影を行
い $1 \mathrm{~mm}$ 間隔で $\mathrm{CT}$ 画像を 15 枚作成した。各画像を画像処理 ソフト(Scion Image)により点データに変換した。なお、 撮影にあたって被検者に対して、本研究の目的および方法を 説明し、同意を得て行った。

\section{2 有限要素モデルの作成}

抽出した点データを有限要素ソフト CosmoS/M Ver2.8(珠) SRAC)に取り込んだ。図 2.1 に示すように同ソフトにより各 断面上の点データを重ね合わせ外科的治療の前の下顎骨モ デルとした。

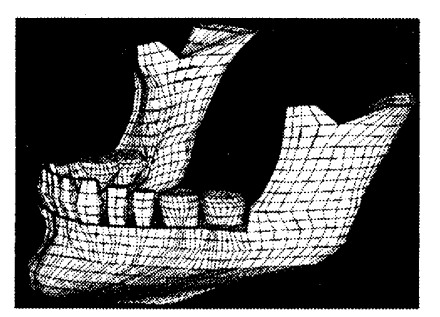

Fig2. 1 Three-dimensional model constracted from CT 
このモデルに下顎枝矢状分割法により図 2.2 に示すように 下歯層神経の部位を避けて内側および外側の各面に骨切り を行い、2 種類のプレートを使って骨接合したモデルを作成 した。次に CT 画像で上類の前歯と下頽の前歯の間隔と、上 額の前歯の厚みから下顎体の後方への移動量を $7 \mathrm{~mm}$ とし内側 骨片を後方へ移動した。I 型及び L 型各プレートはチタン製 で厚さ $0.55 \mathrm{~mm} ，$ ネジは直径 $2 \mathrm{~mm}$, 長さが $5 \mathrm{~mm}$ の物を用い た。

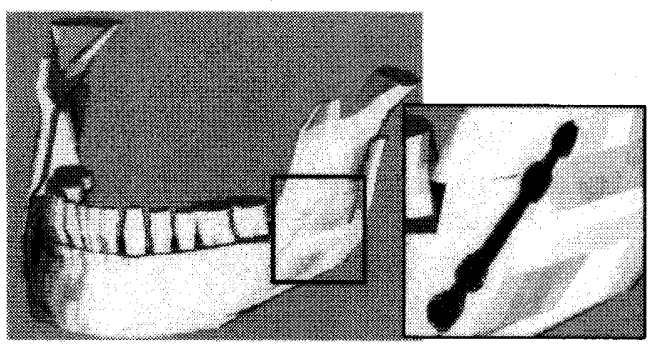

(a) I-type plate

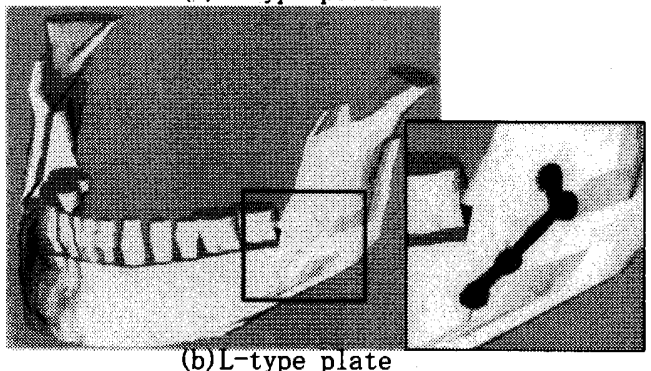

Fig2. 2 FEM models with plates after bilateral sagittal split osteotomy

\section{3 力学的定数の設定}

モデルの材料定数として、皮質骨に $10 \mathrm{GPa}$ 、海綿骨に 500MPa、 歯に $17 \mathrm{GPa} 、$ 骨接合プレートに $986 \mathrm{MPa}$ とし、ポアソン比はす べて 0.3 とした ”。ただし、矢状分割部の骨の接合強度が低 下しているので切断面からの距離によりヤング率が段階的 に上昇するものと仮定した。拘束条件は、下滪枝上部をすべ て完全拘束した。荷重条件は、咬合力として左側第 1 大臼歯 に歯に垂直な力 $41.6 \mathrm{~N}$ を加えた。

\section{3.解析結果および考察}

\section{1 左側中切歯における変位の比較}

図 3.1 に集中荷重を加えた場合の各モデルにおいて得られ た左側中切歯の変位を示す。図において $\mathrm{L}$ 型プレートが小さ な変位を示し高い固定性があることが示唆される。

\subsection{I 型およびL 型プレート上に生じた応力の比較}

図 3.2 に左側骨接合プレートを骨に固定をするための四つ のネジの部分で得られた㐫力分布を示す。図において横軸の $a, b, c$ およびd は、図 3.3 に示すプレート上のねじの位置に それぞれ対応している。図において L 型プレートの場所 $a, b$
は、図 3.3 に示されるように、矢状分割法することにより分 離された近位側の下䅡骨上の場所に対応している。L 型プレ 一ト上の応力が全体的に低く表れている。このプレートが骨 接合に適していると推察される。

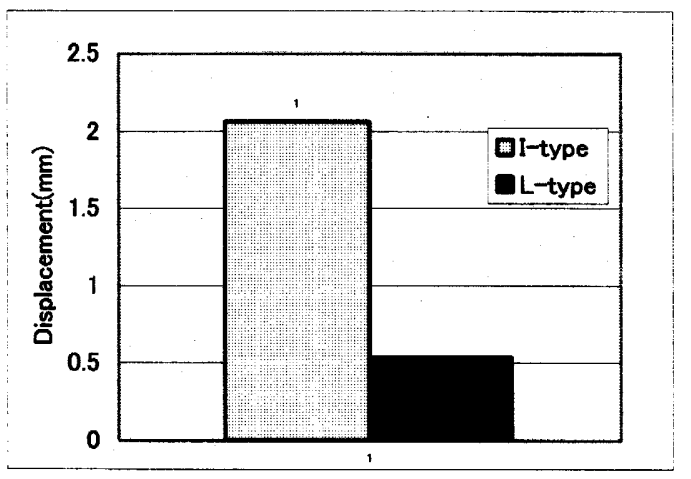

Fig 3.1 Comparisons of the deflection at the left side central incisor

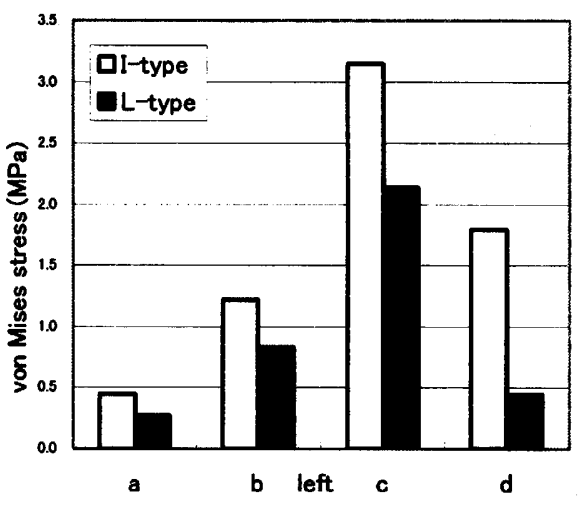

Fig3. 2 Comparison of the von Mises stresses obtained from base, I-type and L-type plates for concentrated load applied to $1^{\text {st }}$ molar.

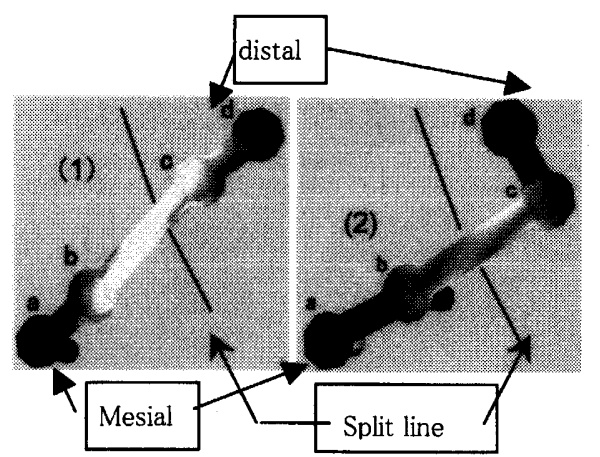

Fig3.3 Stress distributions obtained for I-type and L-type plates (1) I-type (2) L-type 参考文献

(1)前田芳信他，䝷関節の形態的変化に関する生体力学的シミュレー ション 第 1 報:䫟関節部の応力分布に影響を与える因子について, 日頡誌, (1991),3,1-9 